\title{
Influence Green Innovation to Competitive Advantage and Finance Performance Indonesia State Own Entreprise
}

\author{
Dr. Lenggogeni. Ak. MM. CMA. CA. CBV. ACPA \\ \{Lenggo67@gmail.com\}
}

Lecture of Trisakti University

\begin{abstract}
In the current situation, Indonesian state owned enterprises have not reached their performances, which means that their finance performances are relatively low during the late five year period. Their low finance performance are predicted of their competitive disadvantages compare to other private companies which may cause by inappropriate green innovation, either product innovation, process innovation, or market innovation. The objectives of this research were to get (1) the pictures of green innovations; (2) the correlation between the effect of green innovation to the competitiveness advantages; (3) the correlation between the effect of green innovation to the finance performances; (4) the correlation between the effect of competitiveness advantages to the finance performances in the Indonesian state owned enterprises. The methods used in the research were descriptive survey method and explanatory survey method with six proposed hypotheses. Unit analysis in this research is the whole of Indonesian state-owned enterprises.Model structural equivalent (SEM) is used for the analysis method. From the analysis results, it has been figured out that green innovation that has been done utilize their competitive resources but it isn't optimalization (unmarket oriented). Green Innovation have a significant positive effect than the competitiveness advantages in the Indonesian state owned enterprises. Meanwhile Green Innovation has positif effect to the Finance performances in the Indonesian state owned enterprises. Competitive advantages have shown a significant positive effect to the marketing performances in the Indonesian state owned enterprises.
\end{abstract}

Keywords: Green Innovation; Green Innovation Product; Green Innovation Process and Market; Competitiveness Advantages; Finance Performance

\section{Introduction}

State Own Entreprise is the locomotive of economic development and is a mainstay for the national economy and helps determine the direction of Indonesia's economic development in the future. However, the contribution of SOEs to the state since before the pandemic has declined. According to data from the Ministry of SOEs, Indonesia State Own Entreprises have 
revenued decrease in the last 3 years, from Rp. 2,339 trillion in 2018 to Rp. 1,600 trillion in 2019 to Rp. 1,200 trillion in 2020. Profits have also fallen from Rp. 183 trillion in 2018 to Rp. 124 trillion in 2019 and dropped to IDR 28 trillion in 2020. Indonesia State Own Entrprises assets also rose from IDR 8,145 trillion in 2018 to IDR 8,739 trillion in 2019 but go back to IDR 8,400 trillion in 2020 .

The performance of State Own Entreprises is still not optimal, it has not been able to achieve the target in accordance with the Company's Long-Term Work Plan (RPJP) and the Company's Work Plan and Budget (RKAP) that have been set at the General Meeting of Shareholders. The pandemic period that has been running for more than 1 year has greatly affected the performance of SOEs which tend to continue to decline, especially the value of the company (ROA and ROE). The number of BUMN from 2014 to 2018 is as follows:

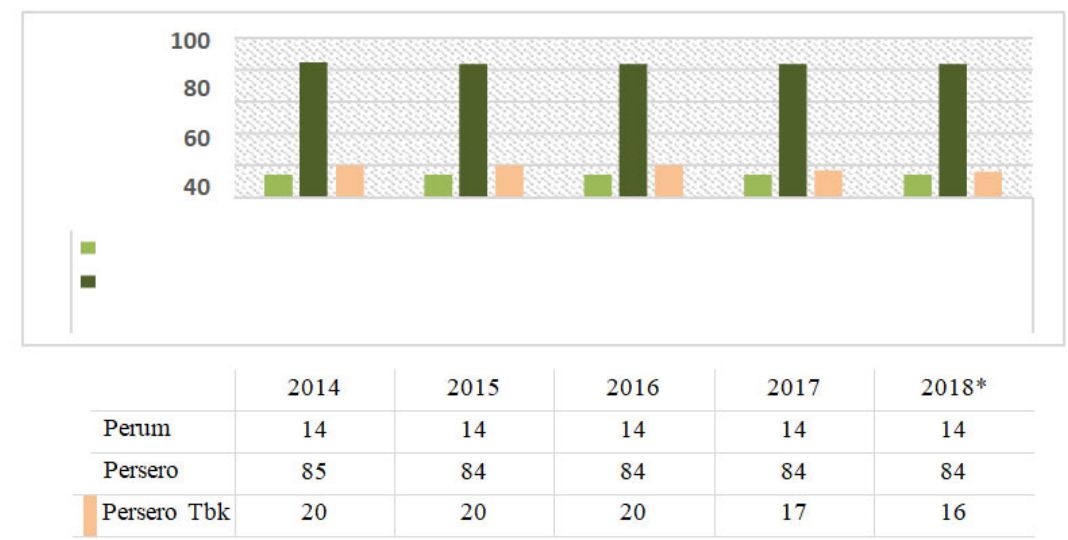

Fig. 1. Indonesia State Own Entreprises 2014 -2018 Source BPS : Performance Report

In environmental concerns, SOEs have incorporated sustainability into their innovation strategy - namely green innovation - to stay competitive and reduce harmful effects on the environment. However, incorporating green innovation needs to be aligned with the company's strategic objectives in order to remain sufficiently profitable [1]. Companies need to answer the critical question of whether involvement in green innovation improves financial performance [2]. Although researchers have extensively investigated green innovation and corporate finance regarding performance relationships, the relevant literature offers only mixed results [3], [4], and fails to resolve managerial issues regarding green innovation and financial performance relationships. For example, literature has reported the existence of a positive relationship between green innovation and financial performance [1], [3], [5], [6].

Due to these mixed findings, green innovation and its relationship to financial performance remains a question for debate, and thus requires further investigation [7]-[9]. We think that the following possible reasons can explain this. Green product innovation and green process innovation affect company performance, especially financial performance and stakeholder performance. According to Michael Porter, green market innovation influences the company's performance. If a company implements green innovation practices, the financial performance and stakeholder performance will increase. Performance is a continuous and flexible process which involves managers and managing partners in a framework that shows them together to 
achieve the desired results [10]. Financial performance is the final result which includes the outcomes of the strategic management process. Company performance is determined by the efficient and effective business strategy implemented

The decline in financial performance is also caused by the company's inability to have a competitive advantage, as stated by Bennett and Smith; Competitive advantage is an advantage that is achieved through superior customer value by creating a competitive strategy to achieve profitability and growth through a match between the company's internal capabilities and market demands. Based on the statement above, it is clear that the low financial performance is thought to be caused by competitive disadvantage [11]. Kholil states that innovation (economy) will improve the financial performance of a company [12]. Innovation as the basis for the creation of products, services or processes that are new for an organization, introduced to the market through the utilization and commercialization of new products, services or processes, it does not have to be something new to the world [13], whether or not ideas have been adopted by other organizations [14]. An innovation can change practice in the industry, which can improve productivity [15].

Joe Todd in the book "Managing Innovation" that Innovation helps capture and retain market share and increase profitability [16]. it is clear that the performance of Indonesia SOEs which has not yet achieved its sales target is also suspected to be due to a lack of proper innovation, including product innovation and process innovation. Financial report Indonesia State Own Entreprise"s said that there are several problems, namely low asset productivity, low profits, inadequate financial and capital structure, not efective Good Corporate Governance (GCG), unbalanced quality and quantity of human resources, lack of cooperation and synergistic activities. between SOEs, and in terms of innovation and green innovation, SOEs have not been able to become the main actors in business innovation. Based on the statements above, it is very important to investigate the effect of green innovation on competitive advantage and financial performance.

\subsection{Research problem}

Based on the problem above, this study are formulated as follows:

a. How are green innovations carried out by state-owned companies in Indonesia.

b. What is green innovation affects the competitive advantage of state-owned companies in Indonesia.

c. What is green innovation affects the financial performance of state owned companies in Indonesia.

d. What is competitive advantage affects the financial performance of state owne companies in Indonesia.

\subsection{Research Purposes}

This research aims to: (1). to produce a study on green innovation by state-owned companies in Indonesia (2) to get the results of testing the effect of green innovation on competitive advantage in BUMN companies in Indonesia. (3) to get the results of testing the effect of green innovation on the financial performance of state-owned companies in Indonesia. (4) to get the results of testing the effect of competitive advantage on the financial performance of state-owned companies in Indonesia. 


\subsection{Benefit Of Research}

Results of the research objectives above, the usefulness of the research can be divided into 2 aspects:

a. Academics, the results of this study are expected to be useful for:

Development of knowledge, a model of Innovation, Competitive Advantage, and Financial Performance, reconceptualization, providing information on various reference for the next researcher

b. Practitioners, the results of this study are expected to be useful as:

Information for solve problems and materials for SOE management, Ministry of SOE to take decisions and determine future steps in the context of business as well as the considerations of policy makers to determine the direction of SOEs.

\subsection{Research Limitation}

Research are limited to the variables studied, that is green innovation, competitive advantage, and financial performance, while the research was conducted at the end of 20142018. and the unit of analysis in this study is a state-owned company in Indonesia by involving company leaders, because the Indonesian government seeks to build the nation's economy through the empowerment of state-owned companies (BUMN) which recently have not been optimal in achieving business performance.

\section{Literature Review}

Green product innovation is product-oriented while green process innovation is processoriented and green market innovation is market-oriented. The implementation of these three innovations will increase the company's competitive advantage [17]. The measurement of green innovation performance is as follows (1) the company chooses the material with the least amount of pollution in the development and product design of the company he company chooses the materials which produce the least amount of pollution for the product design and development; (2) the company chooses materials that consume the least amount of resources and energy for the product design and development; (3) the company uses the least amount of materials for product design and development; (4) companies plan whether their products are easily reused, biodegradable, and recycled for product design and development [18]-[20].

If the company uses environmental technology, the innovation performance of green products will be very good. Companies must focus on environmental management due to environmental pressures [18]. Companies should focus on stakeholder effects on company activities to carry out environmental management [21], [22]. Green product innovation leads the company to provide amazing eco-friendly products and reduce environmental impact. Green product innovation can facilitate companies to seek green opportunities and enter green developing markets. The success of green product innovation can create a sustainable organizational competitive advantage [20]. Green product innovation brings companies to improve their economic performance by finding new markets, product differentiation, increasing sales and enhancing competitive advantage and corporate image [23]-[25]. 


\subsection{Innovation}

Manzano, Kuster, and Vila state that innovation as a new product is created by the company specifically for the market [26]. Innovation is the creation of new products by companies for certain markets. In simple terms, innovation is defined, as the launch of something new. The purpose of launching something new into a process is to bring about a radical big change.

Kholil states that one of the problems in regulating innovation is the variation in the level of understanding, the term innovation is often used by people associated with the term creation (invention) [12]. Innovation comes from the Latin, namely from the word 'innovare' which means 'to make something new'. So, innovation can be interpreted as a process of changing opportunities into new ideas and embedding these ideas into practice or reality. Innovation is a core business process and a specific tool for entrepreneurs, through which they can take advantage of change as a distinct business opportunity or service. This innovation process helps increase quality and reduce costs. This product innovation also affects product quality, but the greater influence is on the name and value

Innovation is quite varied, for example in scale, level of enjoyment and others that can renew the organization. But at an abstract level it is possible to see the basic operating process for example a new product launch must be considering the potential needs and possibilities of new technologies, developing strategic concepts with various options, then creating new products to be launched into the market. Factors to consider in innovating: (1) Different sectors have different priorities and characteristics; (2) Firm size: small firms differ in access to resources and thus require more development; (3) National innovation system: different countries have more/less supporting relationships between institutions and policies; (4) Life cycle (technology, industry): different levels in the life cycle emphasize different aspects of innovation, for example, technology, new industries as opposed to industries that the company has long established; (5) new levels of fun.

Tessa Avrmaete, Jacques Viaene, Eleanor J Morgan and Nick Crawford state that the domain of innovation includes product innovation, process innovation, market innovation and organization innovation. focus on product output that can be seen and enjoyed, process innovation that focuses on innovation in technology and infrastructure or supply chain, and market innovation that focuses on market segment penetration, because the three dimensions of innovation are appropriate to discuss companies from several sectors (as BUMN studied in this study) and is the domain of BUMN, while organizational innovation is the authority of the State Ministry of BUMN, MENPAN and must get approval from the DPR [27]. It is very important to explore some of the features of an innovative organization and identify a characteristic value. Organizational innovation is not influenced by a simple structure but many other dimensions that influence it. Among them are leadership, team work (across departments \& agencies), and participation which is also very important.

\subsection{Competitive Advantage}

The competitive advantage of a company is determined by a marketing strategy that is synchronized with the competitive strategy. As stated by Porter competitive strategy is a combination of the goals the company strives for with the tools (policies) used to achieve these goals or the search for a profitable position in a market as a place of competition [28].

Bennett and Smith, competitive advantage is an advantage that is achieved through superior customer value by creating a competitive strategy to achieve profitability and growth 
[11]. According to Bennett and Smith, indicators of competitive advantage that will be used in this research include Price, Promotion Skill, Speed of Service, Established Reputation, Cost Advantage, Product Design, Product Quality, Specialized expertise, Range of expertise, Flair and Creativity, and Personal attention. to client needs, because these eleven indicators of competitive advantage are in accordance with the characteristics of the BUMN studied, such as specialization of expertise, creativity, cost advantage, and attaching importance to product quality to win the competition [29]. However, Day and Wensley state that competitive advantage is defined as a different competition in terms of expertise and resources. It broadly shows what is being researched in the market, namely positional advantage based on superior customer value or achieving lower relative costs [30].

Based on the above statement, competitive advantage is measured by superior customer value which includes the dimensions of benefits with indicators such as promotion skills, speed of service, establish reputation, product design, product quality, specialized expertise, range of expertise, flair and creativity. and personal attention to customer needs. While the cost dimension includes price and cost advantage indicators. In choosing a competitive strategy there are two factors to consider, namely: the attractiveness of a market to provide long-term profit levels and determining the relative position in a market. Thus, the goal of competitive strategy is to find a company's position in a market that allows a company to protect itself against competitive pressures or positively influence pressures.

The market attractiveness for a company in competition is determined by five competitive forces, namely: the threat of entry of new entrants, the threat of substitute products, the bargaining power of buyers, the bargaining power of suppliers, and competition among existing competitors [28]. In turn, the relative position of a company in a market determines the level of profit. To win the competition, a company can create two basic competitive advantages, namely: overall cost leadership and differentiation. These two basic advantages when linked to market coverage can produce three generic strategies, namely: cost leadership and differentiation for broad segments and focus for narrow segments. Directly, competitive advantage through marketing can be obtained from segment differentiation and focus. As is well known differentiation strategy will position the company uniquely to meet the special needs of consumers. In general, the company will provide important value for consumers so that consumers are willing to pay.

\subsection{Finanace Performance}

Company performance appraisal can be done by measuring the performance, company performance measurement can be done using financial and non-financial performance measurement methods or approaches. Sonny Nirsutan marketing performance measurement is more partially oriented, namely in the form of productivity [34].

\subsection{Profitability}

The ability of all companies to operate in the long term depends on achieving a reasonable level of profit. Strategically managed companies have a specific profit target, usually expressed in terms of earnings per share (EPS) or return on equity (ROE). Procter \& Gamble uses earnings per share (EPS) in stating its profitability to measure financial performance. Berkshire has an EPS of \$2.84. also uses earnings per share (EPS) to state its profitability.

Company profitability is part of management performance, therefore the notion of profitability can be related to the understanding of company performance and management 
performance, namely a measure of efficiency and effectiveness in financial management investment in order to obtain maximum profit for companies and investors. Reeder R, Briety $\mathrm{G}$ and Reeder H in Sucherly suggest several ways to measure/evaluate financial performance such as: sales analysis, sales performance analysis, marketing cost analysis, contribution margin analysis, net profit margin analysis, customer satisfaction and loyalty, customer education and experience and return on investment analysis [35].

However, in reality, companies in developing countries focus most of their marketing on their production or operations. Therefore, the companies seek to increase output and instead of meeting customer demands. [36]. Performance is multidimensional in nature. Therefore, performance measurement using single measurement dimension is not able to provide a comprehensive understanding. Performance measurement should use or integrate various measurement dimensions. [37]. However, states that profitability ratios can provide an overview of the company's performance in general. There are several profitability ratios, namely net profit on sales/margin, basic earning power, return on total assets and return on equity. The net profit margin approach is the difference between income and costs, which is a profitability ratio in the form of profits obtained from product sales within a certain time. Sales profit margin or net profit margin is the company's ability to generate profits. Sales profit margin is an element of the profitability ratio. The net profit/sales margin refer to the difference between revenue and costs. The net profit/sales margin is a measure of marketing performance used in this study.

The company performance refer to financial performance generated within a certain period. Financial performance refers to financial management of the company / organization. Financial performances using the following ratio: Return On Assets (ROA), Return On Equity (ROE), Return On Capital Employed (ROCE) (Kaplan dan Norton, 1996). Profitability ratio measure the effectiveness of company operation in generating profit.[39]. Measuring financial performance using profitability ratio may assess the effectiveness of fund utilization (investment). Effectiveness refer to achieving company objectives in terms of funds utilization. The investment result is a basis of measuring the effectiveness of a company.

General Electric uses EPS, ROE, and return on total capital (ROTC) to measure its profitability. General Electric strives to achieve revenue growth of more than $10 \%$ and ROTC of more than $20 \%$. Exxon Mobil uses return on average capital employed (ROACE) to measure its profitability.

\subsection{Thinking Framework}

In business activities, Financial Performance is a function that determines sales and activities. Financial performance have a broad scope due to internal activities and external activities. Business is a market orientation and commitment to superior customer value. Superior customer value refer to continuous and systematic value creation activities. Cravens dan Piercy states that market orientation is a business orientation. Customer is used as a "focal point" of company's operations. Market orientation involves the use of superior organizational skills and customer satisfaction orientation. Organizations or companies must monitor rapid changes of customer needs and desires (turbulence). [40]. stated that market orientation is a commitment to deliver a number of values to customers and a superior value creation process for customers. Value creation refer to company innovation and improvement. [40].

Bennett and Smith, states that competitive advantage refer to advantage obtained trough superior customer value by creating a competitive strategy to achieve profitability and growth. According to Bennet and Smith, indicators of competitive advantage are Price, Promotion 
Skill, Speed of Service, Established Reputation, Cost Advantage, Product Design, Product Quality, Specialized expertise, Range of expertise, Flair and Creativity, and Personal attention to client needs. [11].

Company performance is a construct (factor) that is commonly used to measure the impact of a company's strategies and programs. Company performance refer to financial performance, marketing performance and human resource performance. Existing studies use financial measures generally accepted to express company performance such as sales volume, net income, net profit margin, ROI, ROE, etc. Hopkins and Hopkins research on company performance uses net profit margin as a measure of company performance. Net profit margin may influence the company's continued activities. [41].

The list of previous studies on Green Innovation, competitive advantage, and company financial performance and its relation is presented in the following table 1:

Table 1. List of Previous Empirical Study

\begin{tabular}{|c|c|c|c|}
\hline $\begin{array}{l}\text { Author/ } \\
\text { Year }\end{array}$ & Purpose & Sample & Conclusion \\
\hline $\begin{array}{l}\text { Chen et. al. } \\
(2006)\end{array}$ & $\begin{array}{l}\text { The purpose of this study is to } \\
\text { examine the effect of the } \\
\text { performance of the green } \\
\text { innovation on competitive } \\
\text { advantage. [18] }\end{array}$ & $\begin{array}{l}\text { Manufacturing, marketing, } \\
\text { R\&D, environmental } \\
\text { protection department } \\
\text { managers of companies in } \\
\text { " } 2003 \text { Business Directory } \\
\text { of Taiwan" of Business } \\
\text { Express Co., Ltd. }\end{array}$ & $\begin{array}{l}\text { It is found out that the } \\
\text { performances of the green } \\
\text { product innovation and green } \\
\text { process innovation are } \\
\text { positively correlated to the } \\
\text { competitive advantage. }\end{array}$ \\
\hline $\begin{array}{l}\text { Lin et al. } \\
(2013)\end{array}$ & $\begin{array}{l}\text { The purpose of this study is to } \\
\text { examine market demand effects } \\
\text { on green product innovation and } \\
\text { company performance in the } \\
\text { motorcycle industry. It tries to } \\
\text { answer two questions: (a) how } \\
\text { does market demand affect a } \\
\text { company's green product } \\
\text { innovation? and (b) how can } \\
\text { green product innovation affect } \\
\text { company performance? [42] }\end{array}$ & $\begin{array}{l}208 \text { responses from four } \\
\text { leading foreign motorcycle } \\
\text { firms in Vietnam. }\end{array}$ & $\begin{array}{l}\text { It is found out that market } \\
\text { demand is correlated to green } \\
\text { product innovation and } \\
\text { company performance; and } \\
\text { green product innovation } \\
\text { performance is correlated to } \\
\text { company performance. It } \\
\text { categorizes three types of green } \\
\text { product innovation and reveals } \\
\text { their effects on market demand } \\
\text { and company performance. }\end{array}$ \\
\hline $\begin{array}{l}\text { Weng at al. } \\
(2015)\end{array}$ & $\begin{array}{l}\text { The main purpose of this study is } \\
\text { to examine the moderating effect } \\
\text { of green produt innovation and } \\
\text { green process innovation on the } \\
\text { relationship between } \\
\text { stakeholders and environmental } \\
\text { performance and company } \\
\text { performance. It also tries to } \\
\text { discover the moderating effect of } \\
\text { innovation orientation in the } \\
\text { relationship between } \\
\text { stakeholders and green product } \\
\text { innovation and green process } \\
\text { innovation [43] }\end{array}$ & $\begin{array}{l}202 \text { responses from } \\
\text { Taiwanese manufacturing } \\
\text { and service companies. }\end{array}$ & $\begin{array}{l}\text { It is found out that employee } \\
\text { conduct, government and } \\
\text { competitor pressures affect } \\
\text { green innovation practices. } \\
\text { Also, there is a moderating } \\
\text { effect of innovation orientation } \\
\text { in the relationship between } \\
\text { employee conduct and green } \\
\text { product innovation practices. }\end{array}$ \\
\hline $\begin{array}{l}\text { Chen et. al. } \\
\text { (2016) }\end{array}$ & $\begin{array}{l}\text { This study points out the } \\
\text { relationships between proactive } \\
\text { and reactive green innovations } \\
\text { and green product development } \\
\text { performance, and the mediating } \\
\text { effect of green creativity [43]. }\end{array}$ & $\begin{array}{l}\text { Members and leaders of } \\
\text { green product development } \\
\text { projects, managers of } \\
\text { manufacturing, R\&D, } \\
\text { marketing, environmental } \\
\text { protection departments of } \\
\text { companies in " } 2003 \\
\text { Business Directory of }\end{array}$ & $\begin{array}{l}\text { It is found out that proactive } \\
\text { green innovation has positive } \\
\text { effects on green creativity and } \\
\text { green product development } \\
\text { performance, and green } \\
\text { creativitiy has positive effects } \\
\text { on green product development } \\
\text { performance. It is also found }\end{array}$ \\
\hline
\end{tabular}




\begin{tabular}{|c|c|c|c|}
\hline $\begin{array}{l}\text { Author/ } \\
\text { Year }\end{array}$ & Purpose & Sample & Conclusion \\
\hline & & $\begin{array}{l}\text { Taiwan", of Business } \\
\text { Express Co., Ltd. }\end{array}$ & $\begin{array}{l}\text { that green creativity partially } \\
\text { mediates the relationship } \\
\text { between proactive green } \\
\text { innovation and green product } \\
\text { development performance. }\end{array}$ \\
\hline $\begin{array}{l}\text { Chang } \\
(2016)\end{array}$ & $\begin{array}{l}\text { The purposes of this study are to } \\
\text { examine the effects of corporate } \\
\text { environmental commitment and } \\
\text { green human capital on green } \\
\text { product innovation performance } \\
\text { and to discuss the mediation } \\
\text { effect of green adaptive ability } \\
\text { [20]. }\end{array}$ & $\begin{array}{l}\text { This study was conducted } \\
\text { on } 136 \text { of manufacturing } \\
\text { companies in Taiwan }\end{array}$ & $\begin{array}{l}\text { It is found out that corporate } \\
\text { environmental commitment has } \\
\text { positive direct effects on green } \\
\text { product innovation } \\
\text { performance and positive } \\
\text { indirect effects on green } \\
\text { adaptive ability. }\end{array}$ \\
\hline $\begin{array}{l}\text { Xie et. al. } \\
(2016)\end{array}$ & $\begin{array}{l}\text { The purpose of this study is to } \\
\text { highlight the effects of green } \\
\text { process innovation on the } \\
\text { financial performance of } \\
\text { manufacturing companies by } \\
\text { focusing on the moderating } \\
\text { effects of government subsidies } \\
\text { versus absorptive capability of } \\
\text { industries [44]. }\end{array}$ & $\begin{array}{l}\text { A panel sample of } 28 \\
\text { manufacturing industries } \\
\text { from } \\
2001 \text { to } 2010 \text {, and the } \\
\text { dynamic panel model based } \\
\text { on the literature. }\end{array}$ & $\begin{array}{l}\text { The results reveal that end-of } \\
\text { pipe technologies and clean } \\
\text { technologies are positively } \\
\text { related to financial } \\
\text { performance. Strong absorptive } \\
\text { capacity enhances this } \\
\text { relationship, but green } \\
\text { subsidies decrease this } \\
\text { relationship. }\end{array}$ \\
\hline $\begin{array}{l}\text { Chang } \\
(2018)\end{array}$ & $\begin{array}{l}\text { The purposes of this study are to } \\
\text { verify the framework to examine } \\
\text { the effects of inward and outward } \\
\text { capabilities on competitive } \\
\text { advantage with green service } \\
\text { innovation or green product } \\
\text { innovation performance as the } \\
\text { mediator and to compare the } \\
\text { antecedents of green service } \\
\text { innovation or green product } \\
\text { innovation performance in } \\
\text { service and manufacturing } \\
\text { companies [45]. }\end{array}$ & $\begin{array}{l}\begin{array}{l}161 \text { and } 202 \text { valid } \\
\text { questionnaires }\end{array} \\
\text { weturned } \\
\text { manufacturing and service } \\
\text { companies respectively. } \\
\text { The sample of } \\
\text { manufacturing and service } \\
\text { industries in Taiwan from } \\
\text { the } 2014 \text { Factory Operation } \\
\text { Census of Ministry of } \\
\text { Economic Affairs. }\end{array}$ & $\begin{array}{l}\text { It is found out that when a } \\
\text { company wants to improve its } \\
\text { green product innovation } \\
\text { performance, it should increase } \\
\text { locus of planning and } \\
\text { environmental scanning } \\
\text { capability in a service industry. } \\
\text { On the other hand, when a } \\
\text { company wants to improve its } \\
\text { green product innovation } \\
\text { performance, it should only } \\
\text { enhance environmental } \\
\text { scanning capability in a } \\
\text { manufacturing industry. }\end{array}$ \\
\hline $\begin{array}{l}\text { Xie et al. } \\
(2019)\end{array}$ & $\begin{array}{l}\text { The purposes of this study are to } \\
\text { examine the relationships } \\
\text { between green process } \\
\text { innovation, green product } \\
\text { innovation, and [17] }\end{array}$ & $\begin{array}{l}209 \text { listed companies in } \\
\text { heavily polluting } \\
\text { manufacturing industries. }\end{array}$ & $\begin{array}{l}\text { It is found out that green } \\
\text { process innovation has a } \\
\text { positive effect on green } \\
\text { product innovation, and green } \\
\text { process }\end{array}$ \\
\hline
\end{tabular}

The overall framework above, the research paradigm of the relationship between Green Innovation, Competitive Advantage and Financial Performance is formulated, described in schematic form as follows: 


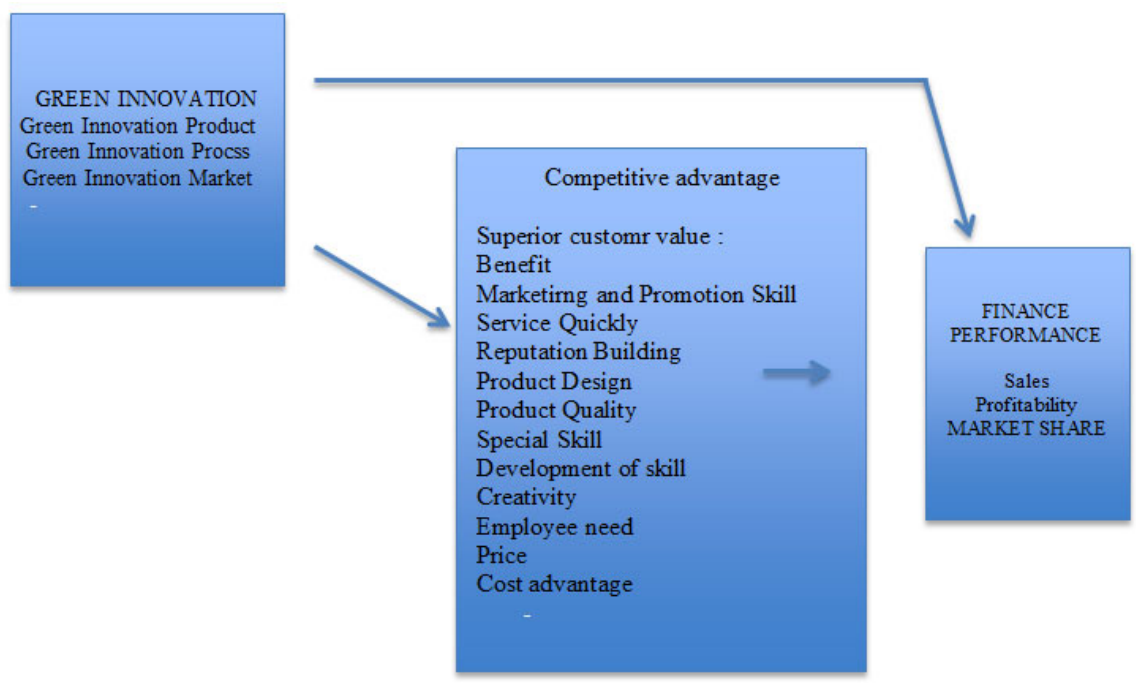

Fig. 2. Paradignm of Research

\subsection{Hypothesis}

There is one descriptive hypothesis that needs to be discussed and 3 verification hypotheses in the research to be tested include:

a. Green innovations carried out by state-owned manufacturing companies in Indonesia are able to adapt to shifts in customer demands for a product.

b. Green innovation affects the competitive advantage of state-owned manufacturing companies in Indonesia.

c. Green Innovation affects the financial performance of state-owned manufacturing companies in Indonesia.

d. Competitive advantage affects the marketing performance of state-owned manufacturing companies in Indonesia.

\section{Research Method}

The object of research that becomes the independent variable in this research is Green innovation which includes green product innovation, green process innovation, and green market innovation. Meanwhile, the dependent variable is competitive advantage and marketing performance.

The nature of this research is verification and descriptive. Descriptive research is research that aims to obtain a description of the characteristics of the variables. The nature of verification research basically wants to test the truth of a hypothesis which is carried out through data collection in the field. Where in this study will be tested whether innovation, competitive advantage and marketing performance. Considering the nature of this research is descriptive and verification carried out through data collection in the field, the research methods used are descriptive survey method (to discuss the formulation of problem no. 1) and explanatory survey method (to discuss the formulation of problems no. 2 to 4 ). 
The unit of analysis in this study is a state-owned company with 113 state-owned enterprises involving each of the company's leaders, so that a total of 113 are company leaders. The time horizon in this study is cross-sectional, where the research is carried out simultaneously.

Table 2. Methode

\begin{tabular}{cccc}
\hline $\begin{array}{c}\text { The aim of the study } \\
\text { (T1 s/d T7) }\end{array}$ & Item of Research & Research Methode & Source of data \\
\hline T1 & Descriptive & Descriptive Survey & Primary \\
T2 & Verification & Explanatory Survey & Primary \\
T3 & Verification & Explanatory Survey & Primary \\
T4 & Verification & Explanatory Survey & Primary \\
\hline
\end{tabular}

\subsection{Operational Variable}

The following are operational variable of this research:

Table 3. Operational Variabel

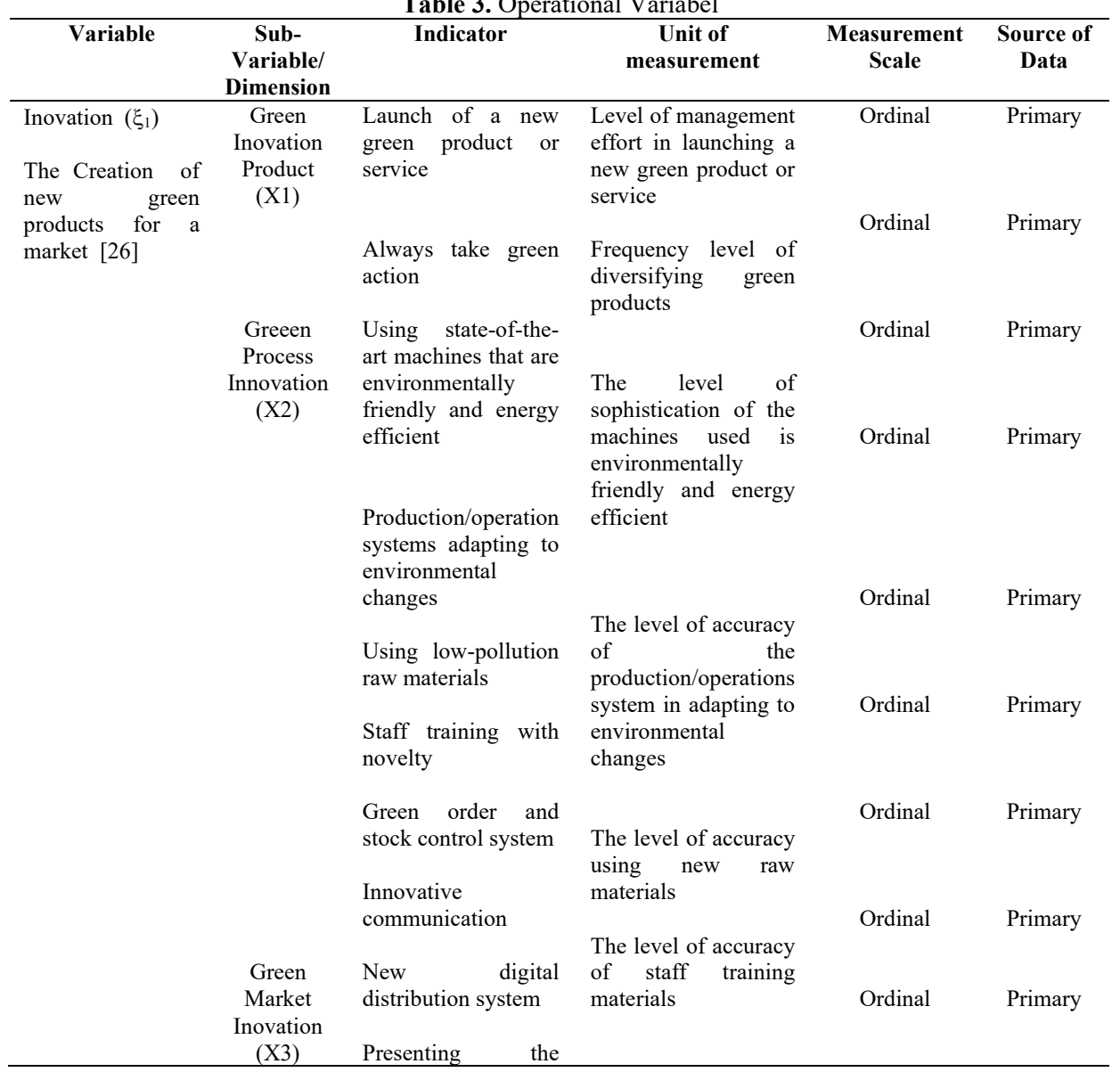




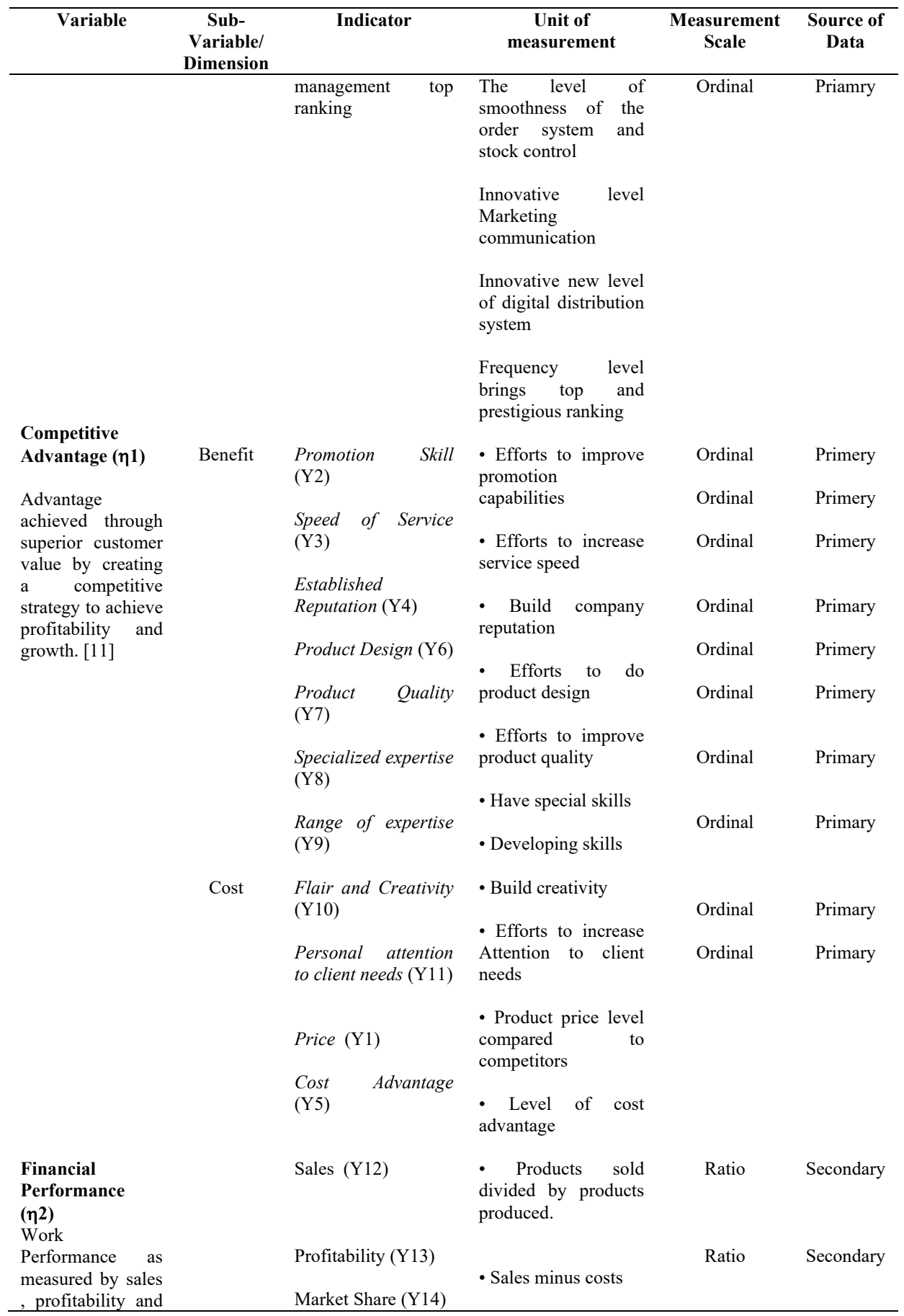




\begin{tabular}{|c|c|c|c|c|c|}
\hline Variable & $\begin{array}{c}\text { Sub- } \\
\text { Variable/ } \\
\text { Dimension }\end{array}$ & Indicator & $\begin{array}{c}\text { Unit of } \\
\text { measurement }\end{array}$ & $\begin{array}{l}\text { Measurement } \\
\text { Scale }\end{array}$ & $\begin{array}{c}\text { Source of } \\
\text { Data }\end{array}$ \\
\hline market share & & & $\begin{array}{l}\text { - Sales volume } \\
\text { divided by total sales } \\
\text { multiplied by } 100 \%\end{array}$ & Ratio & Secondary \\
\hline
\end{tabular}

\subsection{Source and Method of Determining Data/Information}

\subsubsection{Primer Data}

For types of data such as profiles, green innovation and competitive advantage, it is obtained from primary data (through questionnaires).

\subsubsection{Secondary Data}

For data types such as financial performance (sales results, profitability, and market share); development of the number of Companies; Research Institute ( $\mathrm{R} \& \mathrm{D} /$ Internet); Journal (Emerald Library-London); Magazines (BUMN), results of previous research (Dissertation/Journal), and so on.

\subsubsection{How to Determine Data}

The population in this study were 113 BUMN companies in Indonesia, namely 14 BUMNs in the form of Public Corporations, 83 BUMNs in the form of Persero and 16 BUMNs which were Public Limited Liability Companies.

\subsection{Data collection technique}

In collecting data, various data collection techniques are needed. In this study used a combination of data collection techniques consisting of:

a) Questionnaire. Questionnaires are used for primary data collection, especially for respondents (functional management in state-owned companies).

b) Observation. Observations were made to the data sources in accordance with the units of observation/analysis that have been mentioned per predetermined time period.

\subsection{Analysis Design and Hypothesis Testing.}

To analyze and interpret the data, it is used:

a) Descriptive analysis

This is used especially for qualitative variables, and only presents the incoming data by grouping and tabulating then giving an explanation. This analysis is also used to tested the descriptive hypothesis, namely hypothesis 1 by using a frequency distribution.

b) Quantitative Analysis

Used to measure a study with quantitative data and hypothesis testing 2,3,4 tested using a structural equation model or Structural Equation Modeling (SEM), which is a multivariate technique that examines a series of dependent relationships between variables. Usually used when one dependent variable becomes the independent variable in the next dependent relationship. 
The steps for testing structural equation modeling begin with the use of a covariance matrix that will be taken as input for SEM (structural equation modeling) operations with the following stages:

a) Test the suitability of the model (goodness of fit test) using chi square and probability, with the formula below:

$$
\chi^{2}=\sum_{i=1}^{r} \sum_{i=i}^{c} \frac{(O i j-E i j)}{E i j}
$$

Source: Aczel [46]

b) Test causality (regression weight) using regression coefficients and t-test (t-test), if the Lisrel program has been displayed in the form of path analysis. Each path providesvalue that displays the relationship between variables or indicators.

c) The reliability of the measuring instrument with the standard is 0.70

$$
\text { Construct }- \text { reliability }=\frac{\left(\sum \text { standar loading }\right)^{2}}{\left(\sum \text { standar loading }\right)^{2}-\sum \varepsilon j}
$$

Where:

Standard loading is obtained from each indicator from computer calculations $\mathrm{Ej}$ is the measurement error of each indicator The second reliability measuring tool is as follows with the standard 0.50 .

$$
\text { Variance }- \text { extracted }=\frac{\left(\sum \text { standar loading }\right)^{2}}{\left(\sum \text { standar loading }\right)^{2}-\sum \varepsilon j}
$$

In this study, the variables to be tested for the hypothesis cannot be measured directly, so it is necessary to create a measurement model called linear structural relationships (LISREL) which was introduced by Karl Joreskorg in 1973 [47], except for the financial performance variable that is measured. with sales results, because the size is already a ratio. Based on the research paradigm, it is described that several variables have an indirect relationship, so it needs to be depicted in a path diagram. To test whether the relationship is in accordance with the results of the study, a path analysis was carried out. The research paradigm whose path analysis is made can be used as a model called Structural Equation Modeling (SEM). SEM uses a correlation matrix as input so that the model to be tested has received appropriate and adequate empirical support. The model is then applied in the real world equipped with indicators, because the variables to be tested cannot be observed directly or are called latent variables. Therefore, other indicators must be used so that the variables to be measured can be tested. Testing the indicators of each variable is a manifest variable. So that the analysis of dependencies and interdependencies can be measured the level of testability. The diagram to be tested is converted into notation. 
In selecting the input matrix and model estimation, Structural Equation Modeling (SEM) only uses the variance matrix/covariance matrix because it meets the methodological assumptions better than using the correlation matrix as stated by Hair et al. [48]. Before testing the hypothesis, the most important thing is to test the validity and reliability of the measuring instrument, the point is that in filling out questionnaires by respondents and calculating statistics it will be proven that the list of statements made is indeed valid and reliable. This hypothesis test is intended to accept the null hypothesis about no difference, so an insignificant chi-square value is needed.

Hypothesis testing is needed to find out whether the model mentioned above is in accordance with the research results, so it needs to be tested through a field research. The results of the hypothesis are given in the form of a chi-square value which is certainly very sensitive by the number of samples, therefore several other test tools (fit index) are used to measure the suitability and adequacy of the model (adequacy of the model). Structural equation models can be used in two-way (reciprocal) and recursive causal (causal) models. Parameter estimation is carried out at the same time to create a structural model. The data that has been processed does not need to be standardized, so that it can be directly analyzed from the raw data. The output of the structural equation model is in the form of determinant factors, so it can be used to test the relationship and influence. The overall structural equation model is described in Figure 3.

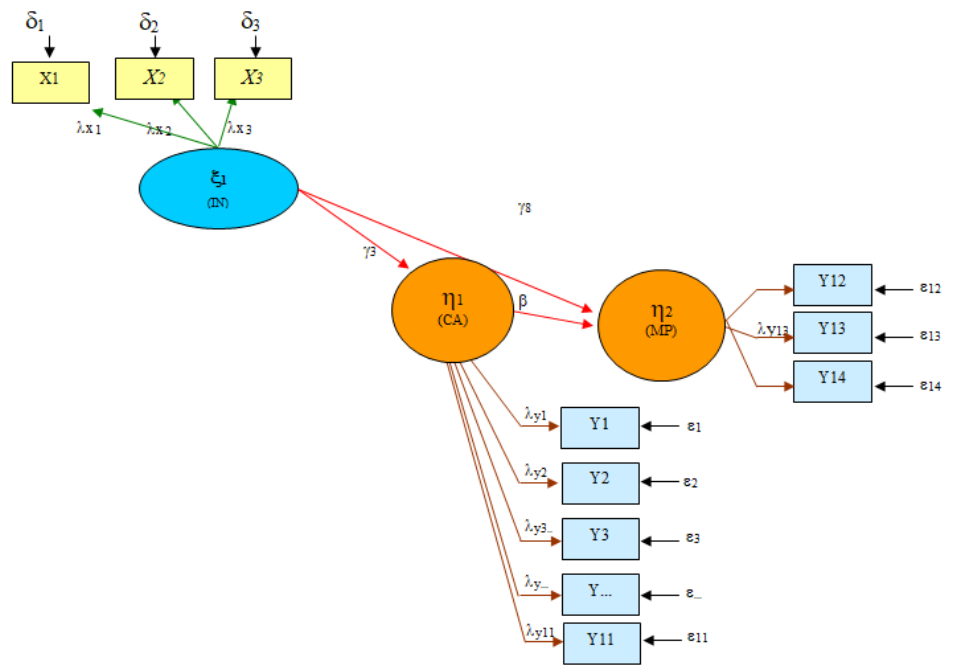

Where:

Fig. 3. Structure Equation Model

$\xi_{1}=$ Green Innovation (IN)

$\eta_{1}=$ Competitive Advantage (CA)

$\eta_{2}=$ Financial Performance (MP)

Hypothesis 1 Green innovation has been carried out by state-owned companies through the development of green products, green processes, and green markets as well as the transformation of resources in order to provide new benefits for customers, utilize core competencies, and manage business partners. 
Hypothesis 1 above was tested by looking at the average score of each variable studied [49]. The logic of calculating the smallest average score is if all respondents answered "1", then the score is $1 \times 370$ (population size) which is 370 , as well as the largest average score is if all respondents choose "5", then the score is $5 \times 370$ (population size) is 1850 . Therefore, it can be grouped if the average score of the variables studied is 370 to 925 , the descriptive hypothesis is rejected, and if the score is 926 to 1850 , the hypothesis is accepted.

Hypothesis 2 Green Innovation has a positive effect on the competitive advantage of State Own Entreprise in Indonesia.

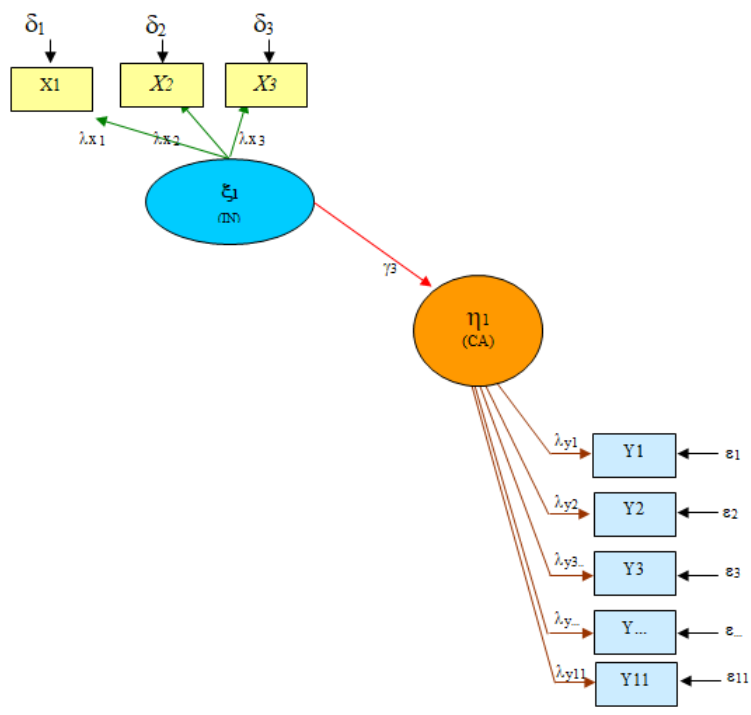

Fig. 4. Structural Model for Hypothesis 2

Hyphotesis 3

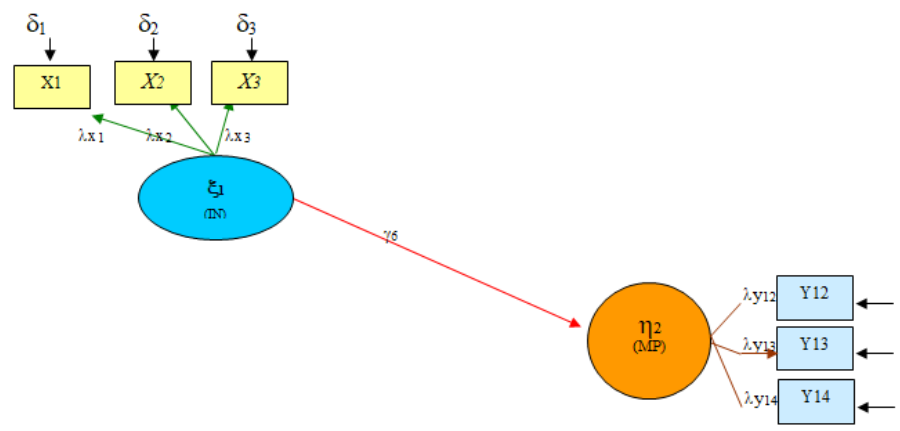

Fig. 5. Structural Model for Hypothesis 3

Hypothesis 3 Green innovation has a positive influence on the financial performance of state-owned enterprises in Indonesia.

Hypothesis 4 Competitive advantage influences the marketing performance of BUMN companies in Indonesia. 


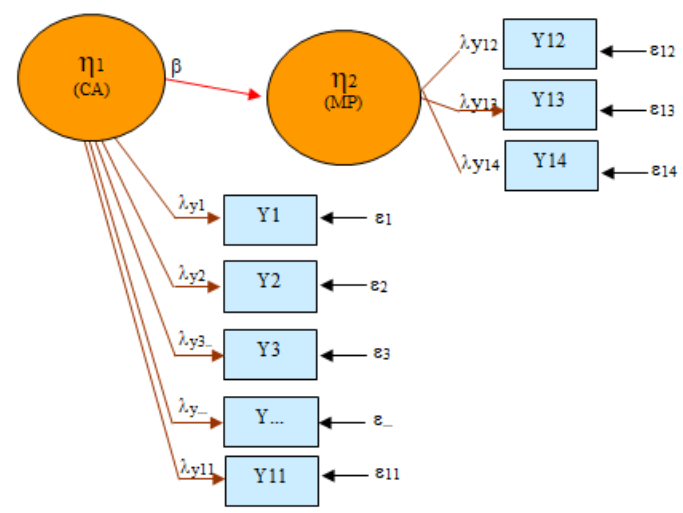

Fig. 6. Structural Model for Hypothesis 4

The formula is as follows:

$\eta_{2}=\mathrm{B} \eta_{1}+\zeta_{4}$

1. Model suitability test (goodness of fit test) is based on goodness of fit standard in index table above.

2. Qualification test using t-test (if using SPSS and Lisrel). Based on AMOS, the CR (Critical Ratio) value is not equal to zero.

\section{Results and Discussion}

\subsection{Green Innovation that has Been Carried Out by State-Owned Enterprises}

Indonesia State Owned Entreprisses hacve done green innovation product, process and marketing with optimalization resource available namely human resources, natural resources, etc . we can see below:

Table 4. Green Innovation carried out by di Indonesia State Owned Entreprises

\begin{tabular}{clcc}
\hline No. & \multicolumn{1}{c}{ Indicator of Green Innovation } & \multicolumn{2}{c}{ Total } \\
\cline { 3 - 4 } & & Total & Score \\
\hline 1 & Launching New Green Product and New Green Process & 113 & 531 \\
2 & Diversification Green Product Diversification & 113 & 488 \\
3 & New business processes applied in production process & 113 & 499 \\
4 & Provision of green new services or products & 113 & 485 \\
5 & Train Staff & 113 & 508 \\
6 & Marketing Communications conducted by SOEs. & 113 & 473 \\
7 & The distribution system carried out by SOEs & 113 & 542 \\
8 & Presenting the top and prestigious products to the public/customers & 113 & 537 \\
Average Score & 113 & 505,7 \\
\hline
\end{tabular}

From the table above, it is clear that in general SOEs have the highest score (542) in innovating products and processes, because SOEs have innovated the market, produced 
products according to customer needs, and built a wider distribution network making it easier for customers to get it, efficiency operating costs, lowering the cost of products so that prices are competitive and can increase sales, profits and market share. While the lowest score is that SOEs innovate in marketing communications (473) because the SOE product market is still on a national scale and tends to be a captive market. The test results above show that there are 8 indicators that can be used to measure product, process and market innovation in all BUMN groups (manufacturing, services, genetics, extraction). Monzano, Kuster and Villa propose 10 indicators of product, process and market innovation. The ten indicators can be used only by manufacturing companies [26].

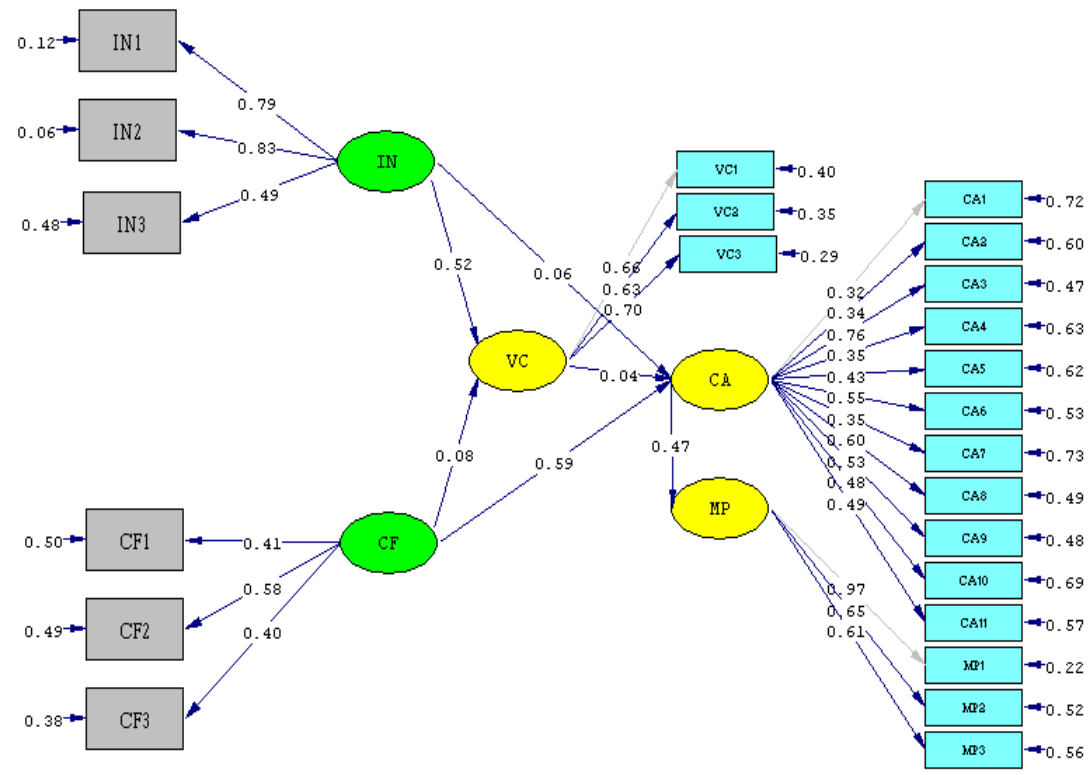

Chi-Square $=672.55, \mathrm{df}=223, \mathrm{P}-\mathrm{value}=0.00000, \mathrm{RMSEA}=0.020$

Fig. 7. Overall Model Structural Diagram (Standardize)

Where :

IN $=$ Green Innovation

$\mathrm{CA}=$ Competitive Advantage

$\mathrm{MP}=$ Financial Performance

Based on the results of data processing using LISREL 8.80, the results obtained for model testing with descriptive sizes GFI $=0.90$ and AGFI $=0.93$, close to one. This means that the proposed model is acceptable. The following is the t-value for each path, as shown in Figure 8 below: 


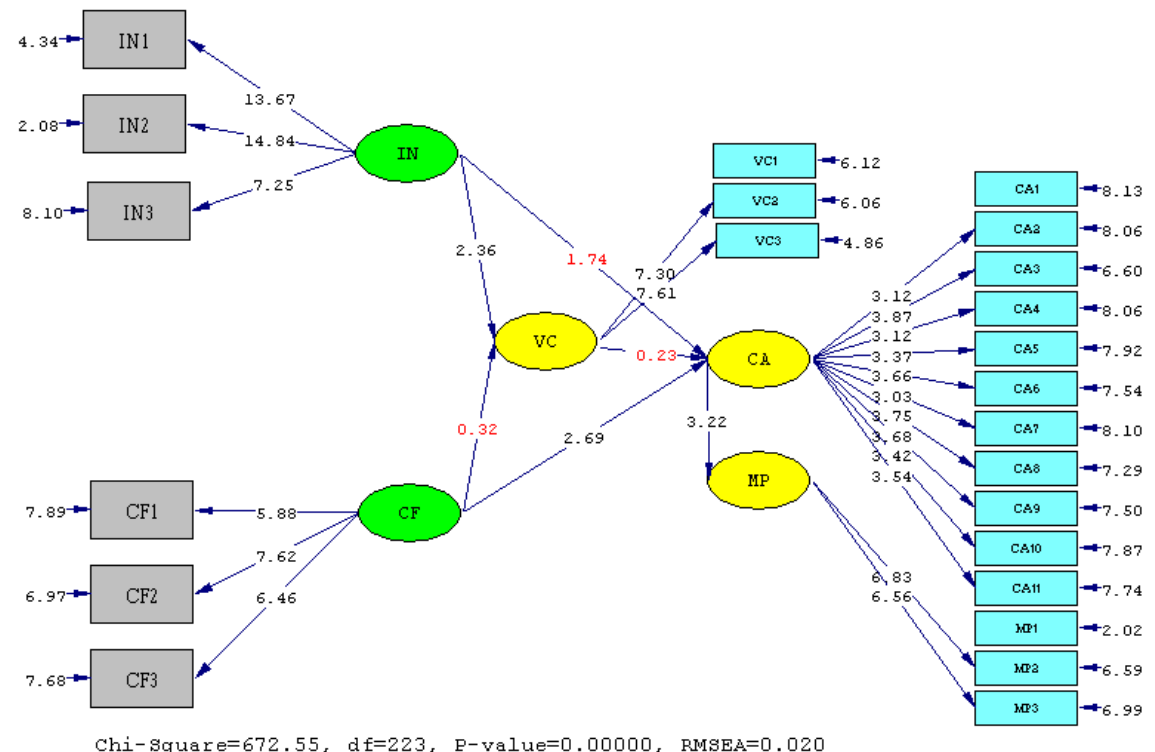

Fig. 8. Overall Model Structural Diagram (t-value)

\subsection{Innovation Affects the Competitive Advantage of Soes in Indonesia}

The second hypothesis describes the relationship between the elements of innovation, which affect the competitive advantage of state-owned companies in Indonesia. The results of the analysis of the fourth hypothesis are described in the path diagram contained in Figure above. Based on the results of data processing using LISREL 8.80, the results obtained for model testing with descriptive sizes GFI $=0.90$ and AGFI $=0.93$, close to one. This means that the proposed model is acceptable.

The factor model or measurement model is a model that relates each latent variable to its indicator variable. In this study, the latent variable of competitive advantage has eleven indicators, namely: Price ( $\left.\mathrm{Y}_{1}\right)$, Promotion Skill $\left(\mathrm{Y}_{2}\right)$, Speed of Service $\left(\mathrm{Y}_{3}\right)$, Established Reputation $\left(\mathrm{Y}_{4}\right)$, Cost Advantage $\left(\mathrm{Y}_{5}\right)$, Product Design $\left(\mathrm{Y}_{6}\right)$, Product Quality $\left(\mathrm{Y}_{7}\right)$, Specialized expertise $\left(\mathrm{Y}_{8}\right)$, Range of expertise $\left(\mathrm{Y}_{9}\right)$, Flair and Creativity $\left(\mathrm{Y}_{10}\right)$, dan Personal attention to client needs $\left(\mathrm{Y}_{11}\right)$.

The following is a standardized parameter estimate that relates each latent variable to its indicator variable in the process of forming the latent variable, namely competitive advantage.

Table 5. Estimation of Competitive Advantage Parameters

\begin{tabular}{lcc}
\multicolumn{3}{c}{ Table 5. Estimation of Competitive Advantage Parameters } \\
\hline \multicolumn{1}{c}{ Indikator } & Taksiran Parameter & $\mathbf{R}^{\mathbf{2}}$ \\
\hline Price (Y1) & 0,32 & 0.72 \\
Promotion Skill (Y2) & 0,34 & 0,60 \\
Speed of Service (Y3) & 0,76 & 0,47 \\
Established Reputation (Y4) & 0,35 & 0,63 \\
Cost Advantage (Y5) & 0,43 & 0,62 \\
Product Design (Y6) & 0,55 & 0,53 \\
Product Quality (Y7) & 0,35 & 0,73 \\
\hline
\end{tabular}




\begin{tabular}{lcc}
\hline \multicolumn{1}{c}{ Indikator } & Taksiran Parameter & $\mathbf{R}^{\mathbf{2}}$ \\
\hline Specialized expertise (Y8) & 0,60 & 0,49 \\
Range of expertise (Y9) & 0,53 & 0,48 \\
Flair and Creativity (Y10) & 0,48 & 0,69 \\
Personal attention to client needs (Y11) & 0.49 & 0.57 \\
\hline
\end{tabular}

Source : Output LISREL 8.80

Table 5 shows the validity of each indicator that forms the latent variable of competitive advantage. Speed of service has estimated parameter of 0.76 in forming the latent variable of competitive advantage with a reliability of 0.47 . Price has estimated parameter of 0.32 and reliability of 0.72 . Therefore, Speed of service is the most valid indicator in measuring competitive advantage.

Table 6. Hypothesis test of the influence of innovation on competitive advantage

\begin{tabular}{cccc}
\hline Variabel & Standardize & t-Value & Statistic Conclusion \\
\hline Green Innovation $\rightarrow$ competitive advantage & 0,06 & 1,74 & Insignificant \\
\hline Source : Output LISREL 8.80 & &
\end{tabular}

From Table 6 above, it is known that innovation in a partial way has an insignificant effect on competitive advantage. From the data equation above, it is known that the influence of innovation on competitive advantage is $25 \%$ and the remaining $75 \%$ is influenced by other factors not included in the study. This means green innovation to competitive advantage. Therefore, state-owned companies in Indonesia so that green innovation can increase competitive advantage must be supported by other variables. The $75 \%$ contribution of other factors to competitive advantage can be studied further. Appelbaum \& Gallagher state that competitive advantage can also be influenced by learning organizations, communications, Intellectual capital, and evaluations [50].

\subsection{Innovation Affects the Financial Performance of State-Owned Companies in Indonesia}

The fourth hypothesis describes the relationship between the elements of green innovation that affect the financial performance of state-owned companies in Indonesia. The results of the analysis of the fifth hypothesis are described below.

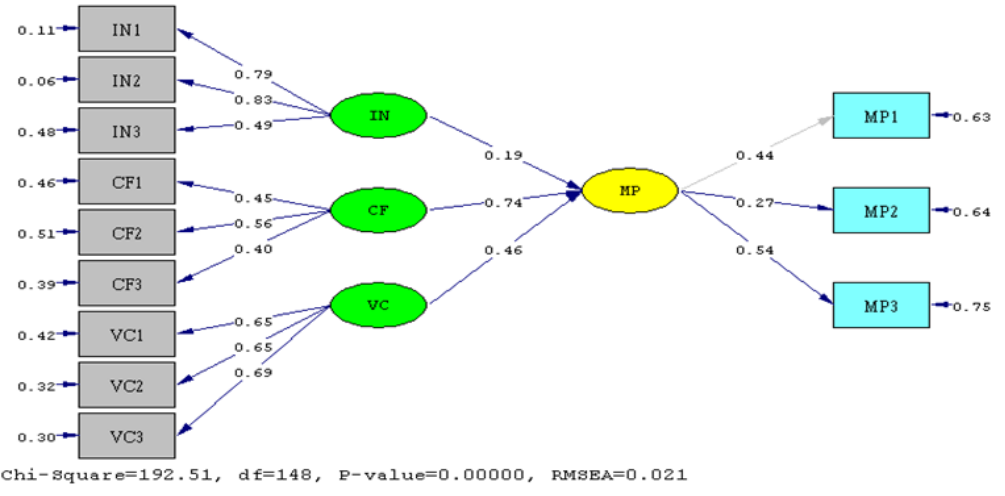

Fig. 9. Structural Diagram Green Innovation to Financial ( $t$-value) 
Based on the results of data processing using LISREL 8.80, the results obtained for testing the model with descriptive measures GFI $=0.90$ and AGFI $=0.90$, close to one. This means that the proposed model is acceptable. The factor model or measurement model is a model that relates each latent variable to its indicator variable. In this study, the latent variable of marketing performance has three indicators, namely sales (Y12), market share (Y13), and profit (Y14). The following is a standardized parameter estimate that relates each latent variable to its indicator variable in the process of forming the latent variable, namely financial performance.

Table 7. Estimated Financial Performance Parameters

\begin{tabular}{ccc}
\hline Indicator & Parameter Estimate & $\mathbf{R}^{2}$ \\
\hline Sales & 0,44 & 0.63 \\
Market share & 0,27 & 0,64 \\
Profit & 0,54 & 0,75 \\
\hline Source: Processed Data using LISREL & 8.80
\end{tabular}

From Table above, it is known that each of the validity indicators that make up the latent variables of marketing performance is known. Profit is an indicator with an estimated parameter of 0.54 in forming the latent variable of marketing performance with a reliability of 0.75. Meanwhile, Market Share with an estimated parameter of 0.27 has a reliability of 0.64 . This means that profit is an indicator that is the most valid indicator in measuring financial performance

Table 8. Hypothesis test of the effect of green innovation on financial performance

\begin{tabular}{cccc}
\hline Variable & Standardize & t-value & Statistic \\
\hline Green Innovation $\rightarrow$ Financial Statistic & 0,19 & 2,39 & Significant \\
\hline Source Processed Data using LISREL & 8.80 &
\end{tabular}

Source : Processed Data using LISREL 8.80

From Table above, it is known that innovation partially has a significant effect on marketing performance, as well as value creation partially has a significant effect on marketing performance. Thus, cross-functional coordination partially significantly influences marketing performance. The effect of innovation, cross-functional coordination, and simultaneous value creation on marketing performance can be seen in equation 3 below:

$\mathrm{MP}=+0.19 * \mathrm{IN}+0.74 * \mathrm{CF}$, Errorvar. $=0.46, \mathrm{R}^{2}=0.54$

From the data equation above, it is known that the effect of innovation, cross-functional coordination, and value creation on marketing performance is $54 \%$ and the remaining $46 \%$ is influenced by other factors not included in the study. These findings are reinforced by research by Walters, Halliday, and Glaser that marketing performance can be achieved through the creation of superior value for customers, market-oriented innovation, and synergistic collaboration between managerial functions [51]. Meanwhile, $46 \%$ of the contribution of other factors to finance performance can be investigated further.

\subsection{Competitive Advantage Affects the Financial Performance of State-Owned Companies in Indonesia}

The fourth hypothesis describes the relationship between the elements of competitive advantage that affect the financial performance of state-owned companies in Indonesia. The results of the analysis of the sixth hypothesis are described in the path diagram contained in 
Figure above. Based on the results of data processing using LISREL 8.80, the results obtained for model testing with descriptive sizes GFI $=0.90$ and AGFI $=0.93$, close to one. This means that the proposed model is acceptable. In this fourth hypothesis, the competitive advantage variable is the latent variable that affects the financial performance variable as the endogenous latent variable. The calculation results are shown in Table as follows:

Table 9. The influence of Competitive Advantage to Financial Performance Hypothesis Test

\begin{tabular}{cccc}
\hline Variable & Standardize & t-value & Statistic Conclusion \\
\hline Competitive Advantage $\rightarrow$ Financial Performance & 0,47 & 3,22 & Significant \\
\hline Source: Processing Results by LISREL 8.8 &
\end{tabular}

From the table above, it is known that competitive advantage has a significant effect on marketing performance. The equation is:

$\mathrm{MP}=0.47^{*} \mathrm{CA}$, Errorvar. $=0.78, \mathrm{R}^{2}=0.22$

$(0.15) \quad(0.16)$

3,22

From the above data equation, it is known that the effect of competitive advantage on marketing performance is $22 \%$ and the remaining $78 \%$ is influenced by other factors not included in the study. These findings are reinforced by research by Walters, Halliday, and Glaser that financial performance

\section{Conclusions}

a. Green innovations that are carried out can actually show that state-owned companies are able to take advantage of the sources of excellence they have but are not yet optimal in meeting market needs.

b. Green Innovation has an insignificant and insignificant effect on competitive advantage in state-owned companies in Indonesia.

c. Innovation, has a positive and significant impact on the financial performance of stateowned companies in Indonesia.

d. competitive advantage has been proven to have a positive and significant impact on the financial performance of state-owned companies in Indonesia.

\section{Suggestion}

Suggestions for Science Development and Goverment Policy. In this study, it turns out that there are still other factors that affect financial performance besides the variables raised in this study, such as the uniqueness of resources, partnership strategies, sources of excellence, and others, because it is expected to examine these other factors, so that the marketing performance of state-owned companies can be further improved and the development of knowledge will continue. 


\section{References}

[1] Y. Li, X. Zhao, D. Shi, and X. Li, "Governance of sustainable supply chains in the fast fashion industry," Eur. Manag. J., vol. 32, no. 5, pp. 823-836, 2014.

[2] J. J. Cronin, J. S. Smith, M. R. Gleim, E. Ramirez, and J. D. Martinez, "Green marketing strategies: an examination of stakeholders and the opportunities they present," J. Acad. Mark. Sci., vol. 39, no. 1, pp. 158-174, 2011.

[3] W. Przychodzeń and J. Przychodzeń, "Corporate Social Responsibility for Sustainability,” Manag. Bus. Adm. Cent. Eur., vol. 22, no. 2, pp. 80-97, 2014.

[4] S. Grewatsch and I. Kleindienst, "When does it pay to be good? Moderators and mediators in the corporate sustainability-corporate financial performance relationship: A critical review," J. Bus. Ethics, vol. 145, no. 2, pp. 383-416, 2017.

[5] S. Kam-Sing Wong, "The influence of green product competitiveness on the success of green product innovation,” Eur. J. Innov. Manag., vol. 15, no. 4, pp. 468-490, Jan. 2012, doi: 10.1108/14601061211272385.

[6] J. Doran and G. Ryan, "Regulation and firm perception, eco-innovation and firm performance," Eur. J. Innov. Manag., vol. 15, no. 4, pp. 421-441, Jan. 2012, doi: 10.1108/14601061211272367.

[7] J. F. Molina-Azorín, E. Claver-Cortés, M. D. López-Gamero, and J. J. Tarí, "Green management and financial performance: a literature review," Manag. Decis., vol. 47, no. 7, pp. 1080-1100, Jan. 2009, doi: 10.1108/00251740910978313.

[8] R. M. Dangelico, "Improving firm environmental performance and reputation: The role of employee green teams," Bus. Strateg. Environ., vol. 24, no. 8, pp. 735-749, 2015.

[9] M. Tariq, T. Abbas, M. Abrar, and A. Iqbal, "E-Word of Mouth and Brand Awareness Impact onConsumer Purchase Intention: Mediating Role of Brand Image," Pakistan Adm. Rev., vol. 1, no. 1, pp. 84-102, 2017.

[10] M. Armstrong, A Handbook of Human Resource Management Practice. London and Philadelphia, PA: Kogan Page, 2006.

[11] R. J. Bennett and C. Smith, "The influence of location and distance on the supply of business advice," Environ. Plan. A, vol. 34, no. 2, pp. 251-270, 2002.

[12] M. Kholil, "Membangun Model Pendayagunaan Hukum Merek Bagi Pengusaha Kecil Dalam Penguatan Masyarakat Ekonomi Kreatif," UNS (Sebelas Maret University), 2019.

[13] Lenggogeni and N. Limakrisna, "Indonesia Soes Building Competitive Advantage," Dinasti Int. J. Econ. Financ. Account., vol. 1, no. 2, pp. 253-263, 2020.

[14] W. Nord and S. Trucker, Implementing routine and radical innovations. Lexington, MA: Lexington Books, 1987.

[15] J. Schumpeter, “The instability of capitalism,” Econ. J., vol. 38, no. 151, pp. 361-386, 1928.

[16] J. Tidd, Managing Innovation. New York: Wiley, 2000.

[17] X. Xie, J. Huo, and H. Zou, "Green process innovation, green product innovation, and corporate financial performance: A content analysis method," J. Bus. Res., vol. 101, pp. 697-706, 2019.

[18] Y.-S. Chen, S.-B. Lai, and C.-T. Wen, "The influence of green innovation performance on corporate advantage in Taiwan," J. Bus. ethics, vol. 67, no. 4, pp. 331-339, 2006.

[19] C. Chang, "Feeling ambivalent about going green," J. Advert., vol. 40, no. 4, pp. 1932, 2011.

[20] C. Chang, "The determinants of green product innovation performance," Corp. Soc. 
Responsib. Environ. Manag., vol. 23, no. 2, pp. 65-76, 2016.

[21] Q. Zhu, Y. Li, Y. Geng, and Y. Qi, "Green food consumption intention, behaviors and influencing factors among Chinese consumers," Food Qual. Prefer., vol. 28, no. 1, pp. 279-286, 2013.

[22] A. J. Hoffman, "Linking organizational and field-level analyses: The diffusion of corporate environmental practice," Organ. Environ., vol. 14, no. 2, pp. 133-156, 2001.

[23] R. M. Dangelico, "Green product innovation: where we are and where we are going," Bus. Strateg. Environ., vol. 25, no. 8, pp. 560-576, 2016.

[24] G. Noci and R. Verganti, "Managing 'green'product innovation in small firms," $R \& d$ Manag., vol. 29, no. 1, pp. 3-15, 1999.

[25] L. Melander, "Achieving sustainable development by collaborating in green product innovation,” Bus. Strateg. Environ., vol. 26, no. 8, pp. 1095-1109, 2017.

[26] J. Aldas-Manzano, I. Küster, and N. Vila, "Market orientation and innovation: an interrelationship analysis," Eur. J. Innov. Manag., 2005.

[27] T. Avermaete, J. Viaene, E. J. Morgan, and N. Crawford, "Determinants of innovation in small food firms," Eur. J. Innov. Manag., vol. 6, no. 1, pp. 8-17, Jan. 2003, doi: $10.1108 / 14601060310459163$.

[28] M. E. Porter, “Competitive Strategy," Meas. Bus. Excell., vol. 1, no. 2, pp. 12-17, Jan. 1997, doi: 10.1108/eb025476.

[29] D. M. Cable and T. A. Judge, "Person-organization fit, job choice decisions, and organizational entry," Organ. Behav. Hum. Decis. Process., vol. 67, no. 3, pp. 294 $311,1996$.

[30] G. S. Day and R. Wensley, “Assessing advantage: a framework for diagnosing competitive superiority," J. Mark., vol. 52, no. 2, pp. 1-20, 1988.

[31] L. Al-Hakim, Handbook of research on driving competitive advantage through sustainable, lean, and disruptive innovation. IGI Global, 2016.

[32] G. J. Hooley and J. A. Saunders, Competitive positioning: the key to marketing strategy. New York: prentice Hall, 1994.

[33] P. Kotler and K. L. Keller, Marketing Management, 13th ed. Singapore: Pearsoan Education, 2009.

[34] S. Nirsutan, Pengukuran Kinerja pemasaran. Jakarta: Rineka Cipta, 2007.

[35] Sucherly, "Strategi Pemasaran Dalam Persaingan Industri Kayu Gergajian Dan Pengaruhnya Terhadap Penjualan,” Disertasi Unpad, Bandung, 1996.

[36] F. Afiff, Strategi Pemasaran, 3rd ed. Bandung: Penerbit Angkaa, 1993.

[37] J. Wiklund, "The Sustainability Of The Entrepreneurial Orientation Performance Relationship," Entrep. Theory Pract., vol. 24, no. 1, pp. 37-49, 1999.

[38] Wetson and Brigham, "Profitability Analysis of Drugs and Pharmaceutical Companies in India," the faculty of commerce, saurashtra university Rajkot, 1992.

[39] S. Adiningsih, Perangkat dan Teknik Analisis Investasi di Pasar Modal Indonesia, 1st ed. Jakarta: PT BEJ, 1998.

[40] D. W. Cravens and N. F. Piercy, Strategic Marketing. New York: Mc Graw Hill, 2006.

[41] W. E. Hopkins and S. A. Hopkins, "Strategic planning-financial performance relationships in banks: a causal examination," Strateg. Manag. J., vol. 18, no. 8, pp. 635-652, 1997.

[42] R.-J. Lin, K.-H. Tan, and Y. Geng, "Market demand, green product innovation, and firm performance: evidence from Vietnam motorcycle industry," J. Clean. Prod., vol. 40, pp. 101-107, 2013.

[43] H.-H. R. Weng, J.-S. Chen, and P.-C. Chen, "Effects of green innovation on 
environmental and corporate performance: A stakeholder perspective," Sustainability, vol. 7, no. 5, pp. 4997-5026, 2015.

[44] H. Xie et al., "Quality of Life in Chinese Family Caregivers for Elderly People With Chronic Diseases," Health Qual. Life Outcomes, vol. 14, no. 1, pp. 1-9, 2016, doi: 10.1186/s12955-016-0504-9.

[45] K. G. Chang, H. Chien, H. Cheng, and H. Chen, "The impacts of tourism development in rural indigenous destinations: An investigation of the local residents' perception using Choice Modeling," Sustainability, vol. 10, no. 12, p. 4766, 2018, doi: $10.3390 /$ su10124766.

[46] A. D. Aczel and J. Sounderpandian, Complete business statistics. Boston. MA: Irwin/McGraw Hill, 1999.

[47] R. Cooper, S. Edgett, and E. Kleinschmidt, "Portfolio management for new product development: results of an industry practices study," $R D$ Manag., vol. 31, no. 4, pp. 361-380, 2001.

[48] J. Hair, R. Anderson, R. Tatham, and W. Black, Multivariate data analysis, 5th ed. New Jersey: Prentice Hall, 1998.

[49] W. G. Zikmund, Bussiness Research Methods, 6th ed. USA: The Dryden Press, 2000.

[50] S. H. Appelbaum and J. Gallagher, "The competitive advantage of organizational learning," J. Work. Learn., vol. 12, no. 2, pp. 40-56, Jan. 2000, doi: $10.1108 / 13665620010316000$.

[51] D. Walters, M. Halliday, and S. Glaser, "Added value, enterprise value and competitive advantage," Manag. Decis., vol. 40, no. 9, pp. 823-833, Jan. 2002, doi: $10.1108 / 00251740210441045$. 